\title{
Onset response of bupivacaine $0.5 \%$ which has been added with sodium bicarbonate on epidural block
}

\author{
Marwoto, Sigit Priyono Raharjo
}

\begin{abstract}
Abstrak
Banyak keuntungan yang ditawarkan pada penggunaan tehnik anestesi epidural, namun dibalik itu terdapat pula beberapa masalah, diantaranya mula kerja yang relatif lama (lebih-lebih bila menggunakan bupivakain); padahal kasus-kasus emergency yang membutuhkan tehnik anestesi dengan mula kerja cepat semakin meningkat akhir-akhir ini. Dilandasi upaya memecahkan masalah tersebut, yaitu mempercepat mula kerja bupivakain, dilakukan uji klinis potong lintang acak buta ganda pada 40 penderita yang akan menjalani bedah abdomen dan ekstremitas bagian bawah dengan blok epidural, untuk mempelajari mula kerja bupivakain dengan penambahan natrium bikarbonat. Subyek diambil secara consecutive sampling dengan kriteria seleksi ASA I - II, umur 20-60 tahun, berat badan 50-60 kg, tinggi badan 150-170 cm. Secara acak subyek tersebut dialokasikan ke dalam 2 kelompok, dimana kelompok perlakuan mendapatkan blok epidural (penusukan pada L3 - 4, posisi tidur miring ke kiri) menggunakan campuran 20 cc bupivakain $0,5 \%+0,5$ cc natrium bikarbonat 1,4\%, sedangkan kelompok kontrol mendapatkan 20 cc bupivakain 0,5\% + 0,5 cc aquabides. Waktu untuk mencapai blok sensorik setinggi dermatom torakal 10 diukur berdasarkan hasil "pin-prick" dan waktu untuk mencapai blok motorik berdasarkan "Skala Bromage". Hasil penelitian menunjukkan pemendekan mula kerja blok sensorik yang sangat bermakna $(p<0,01)$ pada kelompok perlakuan $(10,2 \pm 1,4$ menit) dibanding kelompok kontrol $(19,5 \pm 1,3$ menit $)$. Demikian pula mula kerja blok motorik juga mengalami pemendekan yang sangat bermakna $(p<0,01)$ pada kelompok perlakuan $(13,3 \pm 1,6$ menit) dibanding kelompok kontrol (23,0 \pm 1,2 menit). Disimpulkan bahwa penambahan natrium bikarbonat dapat mempercepat mula kerja bupivakain pada blok epidural. (Med J Indones 2005; 14: 7-10)
\end{abstract}

\begin{abstract}
There are many advantages in using epidural anesthesia technique. However, there are also some constraints, such as the relatively long onset, particularly in the case of bupivacaine. Whereas the need of a rapid onset of anesthesia technique for emergency cares is increasing lately. The objective of this study was to find a method to hasten the onset of bupivacaine. This is a cross sectional randomized double blind controlled clinical trial performed on 40 patients who would undergo lower abdomen and extremity surgery with epidural block. We evaluated the onset of action of bupivacaine which has been added with sodium bicarbonate. Consecutive sampling method was applied to get the sample. The criteria of sample are ASA I - II patient, aged of 20-60 years old, 50-60 kg of weight, 150-170 cm of height. Patients were allocated randomly into two groups. The treatment group would get epidural block using mixture of 20 cc of bupivacaine 0,5\%+0.5 cc of sodium bicarbonate $1.4 \%$, whereas the control group received 20 cc bupivacaine $0.5 \%+0.5$ cc aqua bides. Time to reach sensoric block at the level of thoracal 10 dermatome using the pinprick method and time to reach motoric blockade using the bromage scale was recorded. The result of this study showed a significant shortening of the onset of sensory blockade $(p<0.05)$ in the treatment group $(10.2 \pm 1.4$ minutes) compared with the control group $(19.5 \pm 1.3$ minutes $)$. The onset of motor blockade had also a significant shortening ( $p<0.05)$ in the treatment group $(13.3 \pm 1.6$ minutes) compared with the control group (23.0+1.2 minutes). It was concluded that the addition of sodium bicarbonate can hasten the onset of bupivacaine on epidural block. (Med J Indones 2005; 14: 7-10)
\end{abstract}

Keywords : onset response, bupivacaine $0.5 \%$, sodium bicarbonate, epidural block.

Regional anesthesia has been used for a long time in clinic, since the first use of cocaine drop by Carl Keller in 1884 for eye surgery. ${ }^{1}$ Next, Corning succeeded to inject cocaine into spinal canal (spinal

Department of Anesthesiology and Intensive Care, Faculty of Medicine, University of Diponegoro, Semarang, Indonesia block $)^{2}$ and then in 1901, Hingson ${ }^{3}$ reported his success in caudal block as the only technic to get epidural anesthesia at that time until the finding of lumbal approach by Pagest (1921) in Spain which was easier and more effective. ${ }^{3}$ This technic was used so widely, not only for surgery, but also for painful diagnostic procedure. And it is applicable not only in healthy patients but also in patients with several organ disturbances, from neonates to elderly. 
The wide application of regional anesthesia technic, especially epidural block, is favored by some advantages, such as relative low endocrine metabolic and cardiovascular impact, minimal complication on brain and lung, low risk of thromboemboli, bleeding and aspiration, produce relaxation in whom muscle relaxant drug is contraindicated, adequate analgesia as needed (segmental block) and could be prolonged until post operation (continuous epidural catheterization). ${ }^{4}$

However, there are also some limitations that cause anesthesiologists reluctant to use this technic, i.e. the relatively late onset, limited duration, relatively high failure, unpleasant experience from patient, etc. ${ }^{4}$ Data in the Central Operation Theater (COT) of Dr. Kariadi Hospital Semarang, in 1996, showed that from 4015 surgery, just $421(10,2 \%)$ used regional anesthesia with failure rate of almost $20 \%$. The limited duration of action could be temporarily overcome by addition of adrenoceptor agonist or epidural catheterization, and adequate premedication. ${ }^{4,5}$ What we would like to solve is the first problem, i.e. the late onset of action. The need to hasten the onset is apparently important, considering the increase number of emergency cases that need epidural anesthesia technic with rapid onset.

It is known that local anesthetic drugs are sold as natrium hydrochloride solution to keep high solubility and stability. But in this case, $\mathrm{pH}$ solution is lower than $\mathrm{p} \mathrm{Ka}$, so that non ionized to ionized ratio will move up right. ${ }^{1,2}$ Whereas to penetrate neuron membrane, non-ionized lipid soluble solution is needed. $^{1,2,6}$ So, local anesthetic drugs need extra cellular depolarization process first to change the ionized form into non-ionized. This process takes time that will lengthen the onset of action. Onset of local anesthetic action reflects diffusion of the non ionized lipid-soluble form across nerve membranes. Indeed, local anesthetic with $\mathrm{p} \mathrm{Ka}$ 's nearest physiologic $\mathrm{pH}$ have the most rapid onset of action reflecting the presence of an optimal ratio of ionized to non-ionized fraction. ${ }^{1,2,6}$

Some previous experiments have reported alkalinization technic of mepivacaine such as done by Capogna, et $\mathrm{al},{ }^{5}$ or lidocaine by Tsai, et al and Benzon, et al, ${ }^{6}$ or chloroprocaine by Stevens, et $\mathrm{al}^{7}$ and Ackerman, et al. ${ }^{8}$ They revealed the hasten of the onset of epidural block but with a limited duration. In order to discover local anesthetic with quick onset and long duration, we perform alkalinization study on bupivacaine. In vitro study of alkalinization effect on local anesthetic solution by Berrada ${ }^{9}$ reported that to get optimal $\mathrm{pH}$ of bupivacaine without precipitation; $0.5 \mathrm{cc}$ of $\mathrm{Na}-$ bicarbonate $1.4 \%$ need to be added into $20 \mathrm{cc}$ of its solution.

\section{METHODS}

This is a cross sectional randomized double blind controlled clinical trial performed on patients who would undergo lower abdomen and extremity surgery, with the aim to evaluate the onset of bupivacaine which has been added with sodium bicarbonate on epidural block.

By taking $95 \%$ as the power of the experiment, $5 \%$ as the limit of significance and less than 5\% difference between the two groups is considered clinically significant, 20 samples in each group are needed.

Consecutive sampling method was applied to collect sample or subject of this study. The criteria of subject are: ASA I - II patient, aged of 20-60 years old, 50$60 \mathrm{~kg}$ of weight, $150-170 \mathrm{~cm}$ of height. Patients were allocated randomly into 2 groups. The treatment group would get epidural block using the mixture of $20 \mathrm{cc}$ of bupivacaine $0.5 \%$ and $0.5 \mathrm{cc}$ sodium bicarbonate $1.4 \%$, whereas the control group received $20 \mathrm{cc}$ bupivacaine $0.5 \%$ and $0.5 \mathrm{cc}$ aqua bides. Time to reach sensoric blockade at the level of 10th thoracal dermatome and time to reach motoric blockade was recorded.

An in vitro pre study was performed to find precipitation and to measure the $\mathrm{pH}$ of solution by addition of $0.5 \mathrm{cc}$ Na-bicarbonate $1.4 \%$ in $20 \mathrm{cc}$ bupivacaine $0.5 \%$. pH was measured by $\mathrm{pH}$-meter $\mathrm{P}-400$ type chemtrix single electrode. The $\mathrm{pH}$ of bupivacaine-bicarbonate solution was 6,85 and the $\mathrm{pH}$ of bupivacaine-aqua bidest was 5,6.

Data were analyzed using student $t$ test to compare the onset of anesthesia in the two group of treatment and chi-Square test for distribution of type of surgery. Statistical significance was established at $p$ value of $<0.05$.

\section{RESULTS}

Forty two subjects have been recruited in this study, 40 patients fulfilled study condition, whereas 2 patients were excluded since the block was failed. 
Distribution of type of surgery in the two groups of treatment is shown in Table 1. Crosstabulation between groups and type of surgery shows no significance difference ( $p$ value 0.096).

Table 1. Distribution of type of surgery

\begin{tabular}{lccc}
\hline $\begin{array}{c}\text { Surgery / } \\
\text { Group }\end{array}$ & Treatment & Control & Total \\
\hline Urology & $11(27.5 \%)$ & $10(25.0 \%)$ & $21(52.5 \%)$ \\
Digestive & $5(12.5 \%)$ & $3(7.5 \%)$ & $8(20.0 \%)$ \\
Oncology & $1(2.5 \%)$ & $3(7.5 \%)$ & $4(10.0 \%)$ \\
Ginecology & $2(5.0 \%)$ & $3(7.5 \%)$ & $5(12.5 \%)$ \\
Orthopedy & $1(2.5 \%)$ & $1(2.5 \%)$ & $2(5.0 \%)$ \\
\hline Total & $20(50.0 \%)$ & $20(50.0 \%)$ & $40(100 \%)$ \\
\hline
\end{tabular}

Table 2. Sensoric block onset (minute) for treatment group and control group

\begin{tabular}{clccc}
\hline No. & Group & $\begin{array}{c}\text { Mean } \\
\text { (Minutes) }\end{array}$ & $\begin{array}{c}\text { Std. } \\
\text { Deviation }\end{array}$ & p \\
\hline 1. & Treatment & 10.2 & 1.4 & \\
2. & Control & 19.5 & 1.3 & 0.009 \\
\hline
\end{tabular}

Table 2 shows that the difference in sensoric block onset using student t-test between 2 groups was statistically significant $(\mathrm{p}<0.05)$.

Table 3. Motoric block onset (minute) for treatment group and control group

\begin{tabular}{clccc}
\hline No. & Group & $\begin{array}{c}\text { Mean } \\
\text { (Minutes) }\end{array}$ & $\begin{array}{c}\text { Std. } \\
\text { Deviation }\end{array}$ & p \\
\hline 1. & Treatment & 13.3 & 1.6 & \\
2. & Control & 23.0 & 1.2 & 0.009 \\
\hline
\end{tabular}

The difference in motoric block onset using student t-test between 2 groups was statistically significant $(\mathrm{p}<0.05)$.

\section{DISCUSSION}

Alkalinization of local anesthetic solution was frequently performed by addition of Na-bicarbonate to hasten the onset and increase block potential. This methods has been studied by several experts but the results are still controversial. ${ }^{1,2,10,11}$ Although, almost all local anesthetics were weak alkaline (pKa 7.6-8.9), in this condition the stability and solubility are very low, so that the drugs were sold in natrium hydrochloride solution with $\mathrm{pH}$ of $3.5-6.5 .^{2,12}$ This is suitable with measurement result of bupivacaine $\mathrm{pH}$ in this study, i.e. 5.6.

The dosage used in pre-study experiment was based on the study of Berrada, et al and Bonhomme, et al. ${ }^{9}$ In that pre-study, $\mathrm{pH}$ solution was 6.8 and there was no precipitation until minutes 41 . This results were not different from those of Berrada $(6.9 \pm 0.08$ combine $\mathrm{pH}^{9}$ ) and Bonhomme and they reported that the precipitation was resulted after 40 minutes. Precipitation was not only influenced by $\mathrm{pH}$, but also by the time as showed by the study of Ikuta et al, that emphasized the importance of minimal time interval between alkalinization and injection. In this study, we tried to minimize time interval between alkalinization and injection.

In this study, we used bupivacaine $0.5 \%$, so that not only sensoric block (analgesia) but motoric block (relaxation) were also produced. Bupivacaine 0.75\% was not used in this study because of probable higher systemic toxicity reaction ${ }^{12}$ and not readily available.

Obviously, shortening the onset of local anesthetic by alkalinization technic poses some problems, especially precipitation. Lower precipitation probably can be achieved by using carbonation technic. In this technic, the onset of anesthesia can be hastened by adding $\mathrm{CO}_{2}$ to the local anesthetic. ${ }^{1,2,12}$

Data analysis about onset of both motoric and sensoric block showed statistically significant different between the two groups. This is in accordance with the study of Di Fazio, et al, Tsai, et al, Benzon, et al, ${ }^{6}$ Stevens, et $\mathrm{al}^{7}{ }^{7}$ Ackerman, et al ${ }^{8}$ also Capogna, et al. ${ }^{5}$ However, some other studies such as those of Bedder, et al, Benhamou et al, Ross et al, Glosten et al also Martin, et al produced different conclusion. Bedder, et al studied bupivacaine alkalinization effect in brachialis plexus block, whereas Benhamou, et al also studied that effect on epidural block for caesarean surgery in pregnant woman. They failed to find the significant shortening of bupivacaine onset. ${ }^{7,8,9}$

Theoritically, the increase of $\mathrm{pH}$ by alkalinization is adequate to change ionized form into non ionized. This non-ionized lipid soluble neutral alkali form will penetrate neuron membrane easier, and penetrates axoplasma, then depolarize to bind to specific receptor in sodium channel. This binding blocked the enter of natrium so that depolarization process could not reach 
the threshold to create action potential. ${ }^{13}$ The more the non ionized form available the faster the onset is. ${ }^{13}$

The results of this study were infact influenced by many factors, i.e. subject condition, regional anesthetic technic and methodology, kind and dosage of local anesthetic, the number of sample and statistical analysis methode being used. ${ }^{6,8,9}$

Recent study from Okamura, et al reported a positive linier correlation between the shortening of the onset of local anesthetic and the difference of $\mathrm{pH}$ increase that reached by the solution before injection in in vitro study. ${ }^{14}$ The $\mathrm{pH}$ increase in Glosten's (pH 0.49) and Bedder's study ( $\mathrm{pH}$ 0.88) were relatively small, and was not sufficient to produce non ionized fraction, so that the difference was not detectable. ${ }^{7}$ Alkalinization of local anesthetic solution containing lidocaine with epinephrine (1:200.000) on epidural block by Martin's failed to shorten the onset. This may be due to the fact that all local anesthetic were sold as combination with epinephrine produced with very low $\mathrm{pH}(\mathrm{pH}=$ 3.5) or in very acid condition, to prevent epinephrine oxidation in that solution. ${ }^{2,12}$ Addition of epinephrine has an effect itself, i.e vasoconstriction around local anesthetic pond, that result in loss of alkalinization effectivity. So, in this study we chose single bupivacaine $0.5 \%$ solution without epinephrine combination.

Racle, et al reported that subarachnoid block with alkalinization of bupivacaine $0.5 \%$ failed to find the significant shorter onset. Empirically, the onset of bupivacaine and other local anesthetics in subarachnoid block (without alkalization) is relatively fast. This condition is different from that of bupivacain in epidural space. In epidural space, to reach spinal neuron root, bupivacaine must penetrate dural cuffs, perineural sheath and neuron membrane. ${ }^{1,4}$

In subarachnoid space, bupivacaine could just entered corda spinal and spinal neuron root so that it just needed to penetrate neuron membrane. ${ }^{1,4}$

\section{CONCLUSION}

This study proved that addition of $0.5 \mathrm{cc} 1.4 \%$ natrium bicarbonate into $20 \mathrm{cc} 0.5 \%$ bupivacaine solution could hasten bupivacaine onset in epidural block.

\section{Acknowledgment}

I am very grateful to have the support from Prof. dr. M. Roesli Thalib, Sp An K I C, from Department of Anesthesiology and Reanimation, Faculty of Medicine, University of Indonesia.

\section{REFERENCES}

1. Lofstrom JB, Bengtsson M. Physiology of nerve conduction and local anesthetic drugs. In : Healy TEJ, Cohen PJ, eds. Wylie and Churchill-Davidson's A practice of anesthesia. Boston : Little Brown and Company, 1995 : 172-87.

2. Gaiser RR. Pharmacology of local anesthetics. In : Longnecker DE, Murphy SL, eds. Introduction to anesthesia. Philadelphia : WB Saunders Company, 1997 : 201-14.

3. Satoto D. Analgesia kaudal. Dalam : Kumpulan naskah kursus regional anestesi. Surabaya : RSUD Dr. Soetomo, $1997: 1-18$.

4. Brown DL, Dinese CJ. Spinal, epidural and caudal anesthesia. In : Miller RD, ed. Anesthesia $5^{\text {th }}$ ed. Philadelphia : Churchill Living Stone, 2000 : 1377-402.

5. Capogna G, Celleno D, Tagariello V. The effect of $\mathrm{pH}$ adjustment of $2 \%$ mepivacaine on epidural anesthesia. Reg Anesth 1993; 14 (3) : 121-3.

6. Benzon HT, Toleikis JR, Dixit P. Onset, intensity of blockade and SSEPs changes of the lumbosacral dermatomes after epidural anesthesia with alkalinized lidocaine. Anesth Analg 1993; 76 (2) : 328-32.

7. Stevens RA, Chester WL, Schubert A, et al. $\mathrm{pH}$ adjustment of 2-chloroprocaine quickens the onset of epidural anaesthesia. Can J Anaesth 1995 : 36 (5) : 515-8.

8. Ackerman WE, Denson DD, Juneja MM, et al. Alkalinization of chloroprocaine for epidural anesthesia : effect of pCO2 at constant pH. Reg Anesth 1996; 15 (2) : 89-93.

9. Berrada R, Chassard D, Bryssine S. In vitro effects of the alkalinization of bupivacaine and lindocaine. Ann Fr Anesth Reanim 1994; 13(2) : 165 - 8 .

10. Sweitzer BJ. Local anesthetics. In : Davison JK, Eckhardt WF, Perese DA, eds. Clinical anesthesia procedures of the Massachusetts general hospital. Boston : Little Brown and Company, $1993: 197$ - 205 .

11. Sunaryo. Anestetik lokal. Dalam : Gan S, ed. Farmakologi dan terapi. Edisi IV. Jakarta : BP FKUI, 1996 : 208 - 21

12. DiFazio CA, Rowlingson JC. Additives to local anesthetic solutions. In : Brown DL, Factor DA, ed. Regional anesthesia and analgesia. Philadelphia : WB Saunders Company, $1996: 232-9$.

13. Stevens RA. Neuraxial blocks. In : Brown DL, Factor DA, eds. Regional anesthesia and analgesia. Philadelphia: WB Saunders Company, 1996 : 336 - 44.

14. Okamura BA, Reisner LS, Kalichman MW. Effects of pH adjusted lidocaine solutions on the compound action potensial in intact rat sciatic nerves. Anesthesiology 1990; 67: 281-4. 